\title{
ATAD5 wt Allele
}

National Cancer Institute

\section{Source}

National Cancer Institute. ATAD5 wt Allele. NCI Thesaurus. Code C114946.

Human ATAD5 wild-type allele is located in the vicinity of $17 q 11.2$ and is approximately 64 $\mathrm{kb}$ in length. This allele, which encodes AT Pase family AAA domain-containing protein 5 , plays a role in the cellular response to DNA damage. 